\title{
ACUTE TOXICITY EVALUATION OF ETHANOLIC EXTRACT OF ARISTOLOCHIA ALBIDA DUCH. LEAVES ON WISTAR RATS LIVER AND KIDNEY FUNCTIONS
}

\author{
FELIX F. D. GUINNIN ${ }^{*}$, JEAN ROBERT KLOTOE ${ }^{1,2}$, JEAN-MARC ATEGBO ${ }^{1}$
}

1Department of Animal Physiology, Laboratory of Animal Physiology, University of Abomey-Calavi 06 BP 2584 Cotonou (Benin), ${ }^{2}$ Laboratory of Research in Applied Biology, Polytechnic School of Abomey-Calavi, University of Abomey-Calavi (LARBA/EPAC/UAC), Benin Email: guinninf@yahoo.fr

Received: 02 Jan 2017 Revised and Accepted: 19 May 2017

\section{ABSTRACT}

Objective: Aristolochia albida Duch is frequently used by alternative medicine to treat some pathologies like hepatitis. Our main objective was to evaluate the acute oral toxicity of the ethanolic extract of this plant.

Methods: Exploratory tests for acute oral toxicity are performed in vivo on Wistar albino rats in a limit test of $2000 \mathrm{mg} / \mathrm{kg}$ for $14 \mathrm{~d}$ in accordance with the OECD Guidelines 423. The clinical signs were observed every day, followed by measurement of body weight change, the haematological and biochemical examinations were executed and statistical analysis was performed

Results: The various clinical signs observed after administration and for $14 \mathrm{~d}$ were recorded and no mortality was observed. With the exception of white blood cells, mean cell volume and platelets with statistically significant difference in control $(\mathrm{p}<0.05)$, all the haematological parameters showed an insignificant statistical difference to the control ratio ( $p>0.05)$. For biochemical parameters, except blood glucose and total protein of control batches, which show a significant statistical difference after $14 \mathrm{~d}(\mathrm{p}>0.05)$, all the biochemical parameters show the statistically insignificant difference for test and controls batches $(p>0.05)$ as well as the weight variation of the animals.

Conclusion: The ethanolic extract of the leaves of A. albida Duch (EEAr) had not toxic effect on the biochemical and hematological parameters studied at a dose of $2000 \mathrm{mg} / \mathrm{kg}$. The lethal dose is therefore over $2000 \mathrm{mg} / \mathrm{kg}$.

Keywords: Aristolochia albida Duch, Acute toxicity, Lethal dose

(C) 2017 The Authors. Published by Innovare Academic Sciences Pvt Ltd. This is an open access article under the CC BY license (http://creativecommons.org/licenses/by/4.0/) DOI: http://dx.doi.org/10.22159/ijpps.2017v9i7.16887

\section{INTRODUCTION}

Hepatitis is a real public health problem affecting both developed and developing countries. They are most often caused by viruses, but also by toxic substances, alcohol and certain drugs [1]. A. albida Duch is a recurrent plant used in the treatment of viral hepatitis B and C in Benin [2]. It is of the branch of the Magnoliophyta and the great family of the Aristolochiaceae, [3]. Commonly known as white Aristoloche (french), Dutchman's pipe (english), fonwlè (fon), akogun (yoruba, nagot), kaba tèkè (bariba), leki redu (Peuhl) [4] it has a synonym known scientifically under Aristolochia Ledermannii Engl [3]. A. albida is a perennial herbaceous climbing shrub. The leaves are alternate, cordate-ovate, acuminate. The flowers are solitary with a dark brown perianth at the top and greenish pink at the base. The fruit is a capsule about $4 \mathrm{~cm}$ long [5, 4]. Its capsules are longitudinally dehiscent and often quadrivalated and the seeds released are black [4]. Ecologically, it is a species that blooms in July, August and October and then grows in October. It is found in the dense dry forest [5]. Recent studies have focused on the evaluation of the antioxidant activity of different extracts of A. albida after carrying out the phytochemical screening, the determination of the polyphenolic compounds and showed that the ethanolic extract of $A$. albida provides the best antioxidant activity [6]. Despite the use of this plant to improve or cure pathological processes, very little scientific work has been devoted to its biological properties even less the toxicity tests. This study attempts to evaluate the acute toxicity of ethanolic extract of A. albida leaves on Wistar rat's liver and kidney functions.

\section{MATERIALS AND METHODS}

\section{Plant material}

The leaves of A. albida Duch were harvested in Covè (Latitude $7^{\circ} 13^{\prime}$ $8^{\prime \prime} \mathrm{N}$, Longitude $2^{\circ} 20^{\prime} 22^{\prime \prime} \mathrm{E}$, Altitude $102 \mathrm{~m}$ ), department of Zou (Benin), in July 2015 and identified under the number AA 6551/HNB in the national herbarium of Benin.

\section{Preparation of ethanolic extract of $A$. albida (EEAr)}

The collected leaves were shade dried and powdered in a mixergrinder to get a coarse powder. A quantity of $150 \mathrm{~g}$ of the powder of the leaves is soaked and macerated in $750 \mathrm{ml}$ of ethanol, under gentle agitation for one night at room temperature) forming a maceration. Ethanol extract is recovered after filtration using a paper filter; ethanol is eliminated from the filtrate by evaporation under reduced in a rota-evapour pressure.

Ethical notice

The experimental protocol was approved by the Scientific Ethics Committee of the Doctoral School (Life Sciences) of the Faculty of Science and Technology (FAST) at the University of Abomey Calavi (UAC) under the number (UAC/FAST/EDSV/1012105).

\section{Treatment of animals}

Acute oral toxicity tests were carried out on randomly selected Wistar albino rats (140g-174g), aged 9 to $12 \mathrm{w}$. The rats come from the laboratory of Research in Applied Biology and are acclimatized in the Laboratory of Animal Physiology and Experimental Pharmacology (Faculty of Science and Technology of the University of Abomey-Calavi) for two weeks before the beginning of the experiment at a constant temperature of $22 \pm 1^{\circ} \mathrm{C}$ with a cycle of 12 $\mathrm{h}$ of light and $12 \mathrm{~h}$ of darkness. They are fed with granulated feed and ad libitum water without discontinuity in feeding bottles.

\section{Toxicity tests}

The tests were performed in accordance with the guidelines of the Organization for Economic Cooperation and Development (OECD) for the testing of chemicals substances through Method 423 [7]. The ethanolic extract of this plant is dissolved in distilled water and administered to the rats at a rate of $1 \mathrm{ml} / 100 \mathrm{~g}$ of body weight. Control rats had taken instead extract distilled water. They are 
marked for individual identification. The limit test at a dose of 2000 $\mathrm{mg} / \mathrm{kg}$ was chosen because information indicating that A. Alida Duch. Are probably not toxic, that is, the toxicity is likely to be above the regulatory dose limit. The rats were divided into two batches of three rats after blood tests to ensure homogeneity of batches. Control batch (I) had not received extract but distilled water while batch (II) received $2000 \mathrm{mg} / \mathrm{kg}$ of an ethanolic extract of A. Alida; Duch. The animals were observed individually at least once during the first $30 \mathrm{~min}$ and at least twice during the first $24 \mathrm{~h}$ after treatment. Special attention was given to them daily for $14 \mathrm{~d}$ after the administration of the extract. All observations were systematically recorded. Particular attention has been paid to observing the various manifestations of tremors, convulsions, salivation, diarrhea, lethargy, sleep and coma. The change of body weight, the hematological and biochemical parameters are searched.

\section{Body weight}

The individual weight of each rat is determined one hour before administration of the test substance and then at least once a week. The weight changes are calculated and recorded.

\section{Hematological and biochemical examinations}

Portions of the blood are taken from all rats by retro-orbital puncture $24 \mathrm{~h}$ and $14 \mathrm{~d}$ after the extract administration, for hematological and biochemical examinations at the Laboratory of Applied Biology Research of the Abomey-Calavi Polytechnic School. The hematological examinations are carried out using a SYSMEX KX-
N21 automaton according to the method used by [8]. These include the enumeration of red blood cells, white blood cells, platelets and determination of hemoglobin, hematocrit, mean globular volume, average corpuscular content in hemoglobin, average corpuscular concentration in hemoglobin. The biochemical tests are carried out by the kinetic method according to the methodology of [8] using the Semi-automate brand RAYTO. These include the determination of transaminases (ASAT, ALAT), alkaline phosphatase (PAL), bilirubin (free and conjugated), blood glucose, urea, total protein, creatinine.

\section{Statistical analysis}

All data is processed using Microsoft Excel 2010. Minitab version 16. FR. was used for the analysis of the variance (ANOVA One-Way Analysis) for the comparison of the averages. The threshold of significance is $5 \%$.

\section{RESULTS AND DISCUSSION}

\section{Clinical signs observed}

After administration of the extract, the animals were observed individually at least once during the first $30 \mathrm{~min}$ and at least twice during the first $24 \mathrm{~h}$ after treatment. Particular attention was paid to them daily for $14 \mathrm{~d}$ after administration of the substance. Few minutes after the administration of EEAr, we recorded a short agitation period of about 2 to 3 min, mostly in lot (II) and then the animals resumed normal habit. All observations were systematically recorded and summarized in table 1 .

Table 1: Clinical signs observed $24 \mathrm{~h}$ and during the $14 \mathrm{~d}$ after injection of EEAr

\begin{tabular}{lll}
\hline Lots clinical signs & Lot(I) & Lot(II) \\
\hline Salivation & - & - \\
Accelerated breathing & - & ++ \\
Tremors & - & + \\
Sleep & + & ++ \\
Diarrhea & ++ & - \\
Lethargy & - & - \\
Paralysis & - & + \\
Abdominal constrictions & - & ++ \\
Comma & - & - \\
\hline
\end{tabular}

-: absence of signs+: Presence of signs

The in vivo oral toxicity tests of EEAr carried out at a limit test of $2000 \mathrm{mg} / \mathrm{kg}$, did not cause any mortality and the various clinical signs appeared reversible and disappeared after two weeks. Similar results were reported by [9], who by studying the acute and subacute oral toxicity of Aristolochia longa L., noted a mortality at $4000 \mathrm{mg} / \mathrm{kg}$ which was accentuated at $5000 \mathrm{mg} / \mathrm{kg}$ for acute oral toxicity while the mortality was observed at $2500 \mathrm{mg} / \mathrm{kg}$ for subacute oral toxicity.

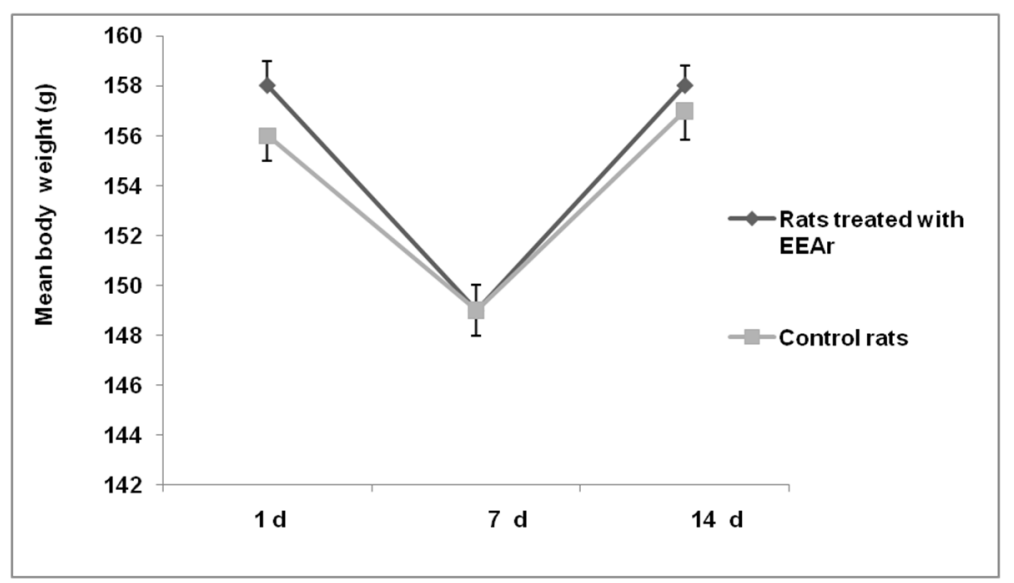

Fig. 1: Effect of EEAr $(2000 \mathrm{mg} / \mathrm{kg})$ on the average weight of wistar rats, $\mathrm{n}=3$, results represent the means $\pm S E M$ (standard error of mean)

The averages obtained are shown on fig. 1 and fig. 2 . There is a variation of average weight over time. $(p>0.05)$. 


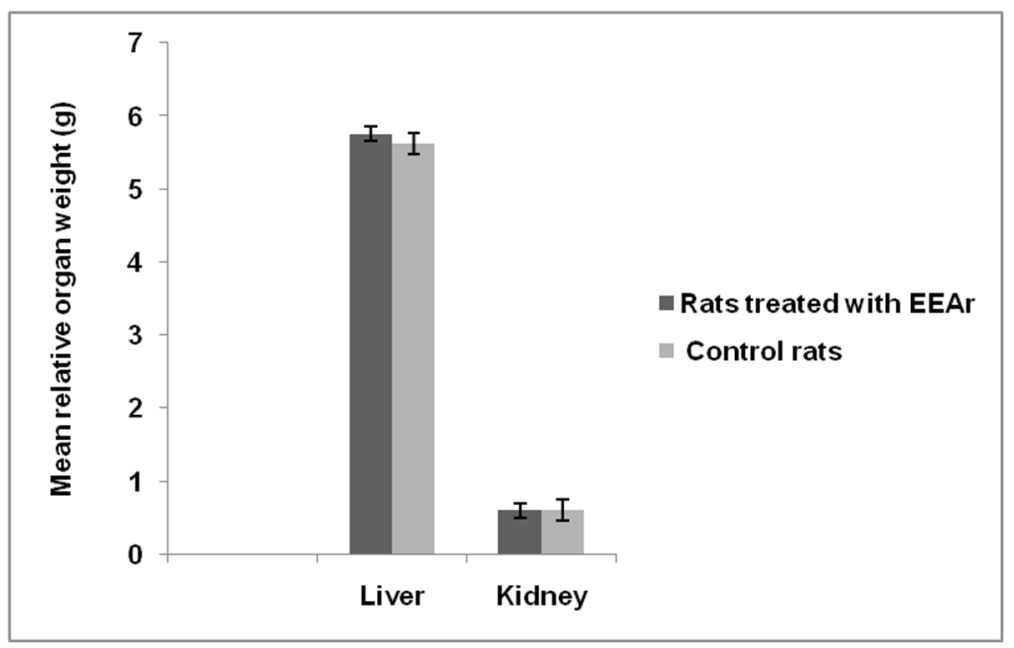

Fig. 2: Effect of EEAr $(2000 \mathrm{mg} / \mathrm{kg})$ on the average weight of the organs, $\mathrm{n}=3$, results represent the means \pm SEM (standard error of mean)

\section{Effect of EEAr on the weight of Wistar rats and their organs}

Analysis of the variation in body weight at the level of the batch having received (EEAr) and the control group showed a slight weight drop $7 \mathrm{~d}$ after treatment (fig. 1). This variation is not significant ( $p>0.05$ ) so it is certainly caused buy other factors such as stress and nervousness of animals during and after swab. The EEAr, therefore, has no effect on the weight change of the animals. On the other hand, previous work has shown that the presence of polyphenols such as tannins can be responsible for poor assimilation of food and can promote a reduction in weight. These results are comparable to the work [10] in the study of the sub-chronic toxicity of Argemone mexicana. In addition, variation in body weight is used as an indicator of the adverse effects of chemical compounds [11].

This weight reduction can be explained by a consumption of food reduction, but also by the possibility of dose/absorption interactions and by the reduction of the quantity of food absorbed. Other studies have also shown the weight reduction of rats after oral administration of the Chicococca alba extract [12] and Stryphnodendron adstringens [13]

\section{Hematological and biochemical examinations}

The results of the hematological examinations are summarized in the following table:

Table 2: Effect of EEAr on blood hematological parameters

\begin{tabular}{lll}
\hline Lot parameters & Lot I & Lot II \\
\hline GB $\left(10^{9} / \mathrm{l}\right)$ & $5.35 \pm 0.07$ & $6.5 \pm 0.25 \mathrm{a}$ \\
HGB $(\mathrm{g} / \mathrm{dl})$ & $14.45 \pm 0.35$ & $10.45 \pm 1.485 \mathrm{~b}$ \\
GR $(10[12] / \mathrm{l})$ & $8.380 \pm 0.255$ & $7.820 \pm 2.942 \mathrm{~b}$ \\
HCT (\%) & $42.500 \pm 3.536$ & $31.900 \pm 1.273 \mathrm{~b}$ \\
VGM (fL) & $51.850 \pm 1.061$ & $61.650 \pm 6.152 \mathrm{a}$ \\
TMH (pg) & $16.100 \pm 1.414$ & $18.200 \pm 1.414 \mathrm{~b}$ \\
CCMH (g/dL) & $31.850 \pm 1.061$ & $29.150 \pm 1.344 \mathrm{~b}$ \\
IDR-CV (\%) & $11.200 \pm 2.970$ & $13.650 \pm 2.192 \mathrm{~b}$ \\
IDR-DS (fL) & $24.500 \pm 1.414$ & $23.000 \pm 3.536 \mathrm{~b}$ \\
PLT (10 $/ \mathrm{l})$ & $534.00 \pm 19.80$ & $718.50 \pm 40.31 \mathrm{a}$ \\
VMP (fL) & $7.700 \pm 1.697$ & $6.700 \pm 2.121 \mathrm{~b}$ \\
IDP & $13.550 \pm 1.768$ & $12.800 \pm 2.121 \mathrm{~b}$ \\
PCT (\%) & $0.6090 \pm 0,1117$ & $0.3845 \pm 0.0912 \mathrm{~b}$ \\
\hline
\end{tabular}

$\mathrm{n}=3$, results represent the means \pm SEM (standard error of mean), a: Significant statistical difference between Lot II and Lot I Control for the parameters considered $(\mathrm{p}<0.05)$, b: Insignificant statistical difference $(\mathrm{p}>0.05) ; \mathrm{M} \pm \mathrm{esm}=$ mean \pm standard error on average, $\mathrm{n}=3, \mathrm{~GB}=$ white blood cells, $\mathrm{HGB}=$ hemoglobin, GR = red blood cells, HCT: Hematocrit, VGM = mean globular volume; TMH = mean hemoglobin content; CCMH = mean corpuscular hemoglobin concentration; PLT = platelets; IDR = red blood cell distribution index; VMP = mean volume of platelets; IDP = Platelet distribution index .

Indeed, it is interesting to note that except the white blood cells and the mean globular volume whose statistical difference compared to the control is significant $(\mathrm{p}<0.05)$, all the hematological parameters present an insignificant statistical difference compared to the control ( $p>0.05)$, for example, the absence of the hematocrit variation leads us to exclude the hypothesis of hemoconcentration. On the other hand, the increase in the levels of white blood cells and platelets suggests that the EEAr leaves stimulates the functions of the immune system as opposed to the methanolic extract of Alstonia scholaris which reduces the content of white blood cells and platelets, weakens the immune system by causing infections [14].

These results are in part similar and contrary to those of [15] and [16] which showed that the total aqueous extract of Sacoglottis gabonensis does not cause changes in the erythrocyte and leukocyte lines. Indeed [15], studying the influence of Sacoglottis gabonensis on the side effects of 2,4-dinitrophenylhydrazine on blood and cell metabolism, showed that administration of Sacoglottis gabonensis to rats did not alter the levels of red globules, hemoglobin, hematocrit, white blood cells, lymphocytes, neutrophils and monocytes.

The various biochemical parameters explored have informed us about the probable effects of EEAr leaves in the liver and kidney. The transaminases (ALAT and ASAT), alkaline phosphatase (PAL), bilirubin (free and conjugated), blood glucose are parameters of the liver while uric acid, creatinine and total proteins are kidney parameters. The results of the various assays are shown in the fig. ranging from 3 to 11 . 


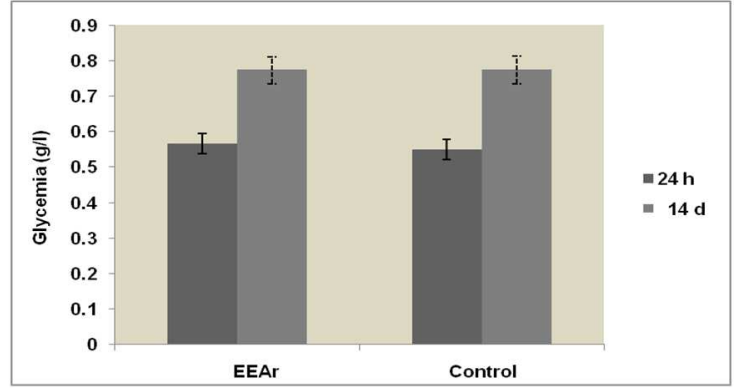

Fig. 3: Effect of EEAr. $(2000 \mathrm{mg} / \mathrm{kg})$ on blood glucose, $n=3$, results represent the means \pm SEM (standard error of the mean)

There was no significant difference $(p>0.05)$ in glucose (lot II) treated with EEar after $14 \mathrm{~d}$, whereas that in the control batch (lot I) showed a significant difference $(\mathrm{p}<0.05)$.

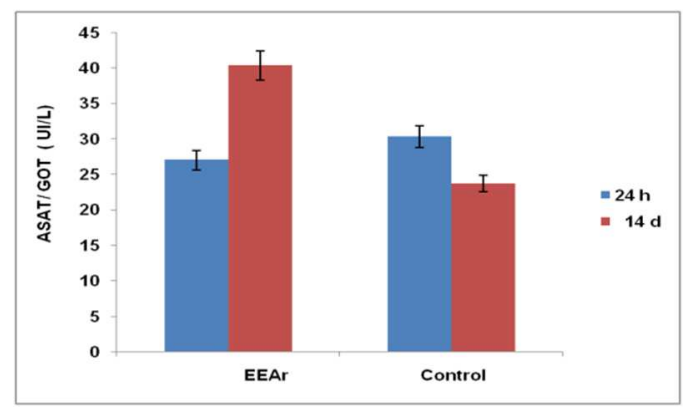

Fig. 4: Effect of EEAr $(2000 \mathrm{mg} / \mathrm{kg})$ on the ASAT transaminase, $n=3$, results represent the means \pm SEM (standard error of mean)

The ASAT transaminase of (lot II) treated with EEar and of the control lot (lot I) showed no significant difference $(p>0.05)$ after $14 \mathrm{~d}$.

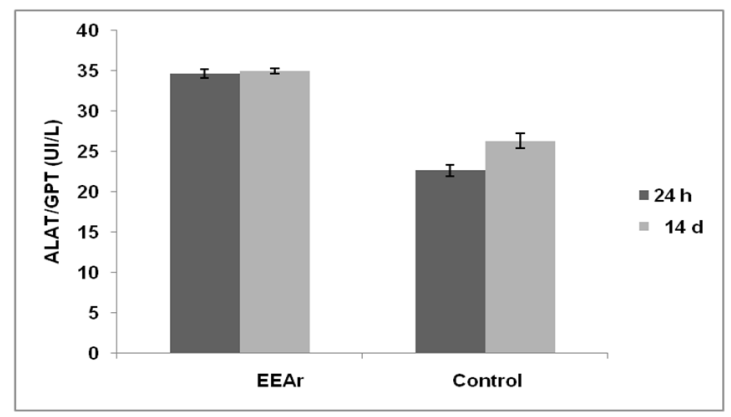

Fig. 5: Effect of EEAr $(2000 \mathrm{mg} / \mathrm{kg})$ on the ALAT transaminase, $\mathrm{n}=3$, results represent the means \pm SEM (standard error of mean)

The ALAT transaminase of (lot II) treated with EEar and of the control lot (lot I) showed no significant difference ( $p>0.05)$ after $14 \mathrm{~d}$.

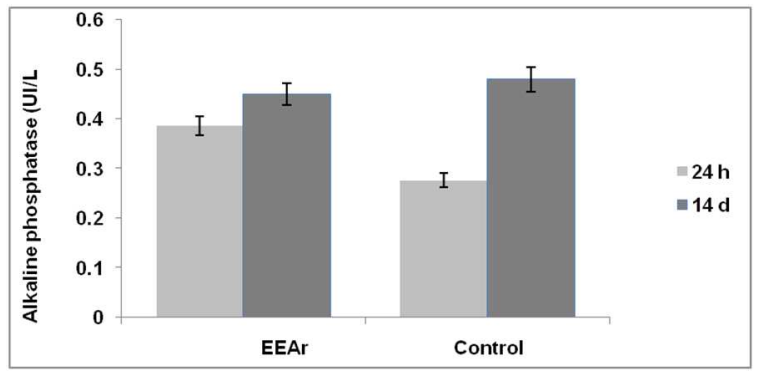

Fig. 6: Effect of EEAr $(2000 \mathrm{mg} / \mathrm{kg})$ on alkaline phosphatase (PAL), $n=3$, results represent the means $\pm S E M$ (standard error of mean)
The alkaline phosphatases (PAL) of (lot II) treated with EEar and of the control lot (lot I) showed no significant difference ( $p>0.05$ ) after $14 \mathrm{~d}$.

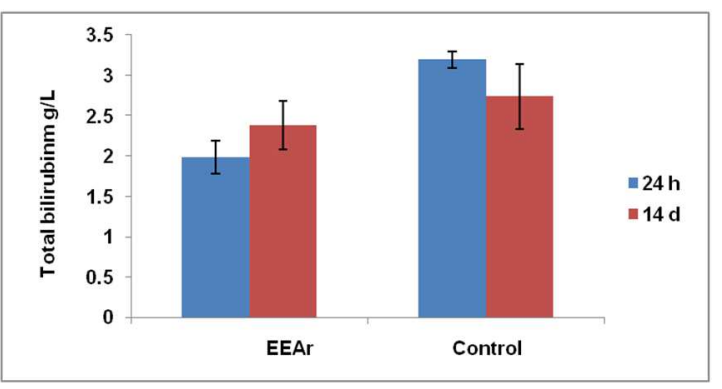

Fig. 7: Effect of EEAr $(2000 \mathrm{mg} / \mathrm{kg})$ on total bilirubin, $\mathrm{n}=3$, results represent the means \pm SEM (standard error of mean)

Total bilirubin (lot II) treated with EEar and control batch (lot I) showed no significant difference ( $p>0.05$ ) after $14 \mathrm{~d}$.

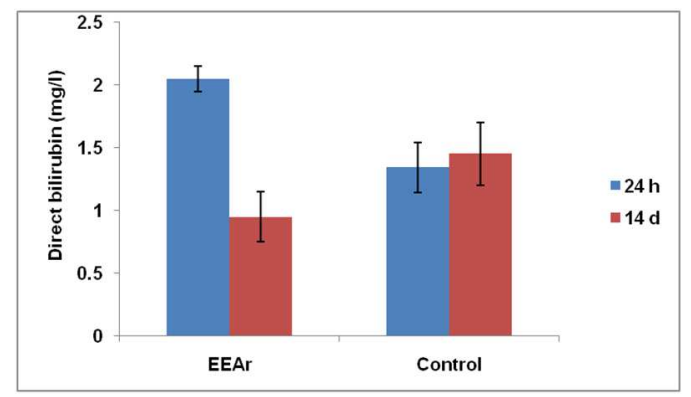

Fig. 8: Effect of EEAr $(2000 \mathrm{mg} / \mathrm{kg})$ on direct bilirubin, $\mathrm{n}=3$, results represent the means \pm SEM (standard error of mean)

The direct bilirubin of (lot II) treated with EEar and the control lot (lot I) showed no significant difference ( $p>0.05$ ) after $14 \mathrm{~d}$.

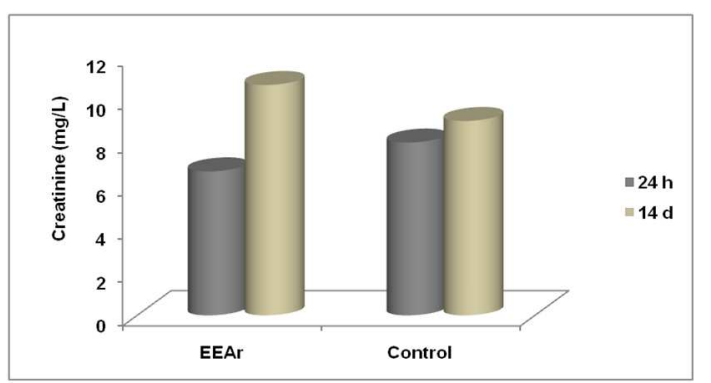

Fig. 9: Effect of EEAr $(2000 \mathrm{mg} / \mathrm{kg})$ on creatinine, $\mathrm{n}=3$, results represent the means \pm SEM (standard error of mean)

Creatinine (lot II) treated with EEar and control (lot I) showed no significant difference $(\mathrm{p}>0.05)$ after $14 \mathrm{~d}$.

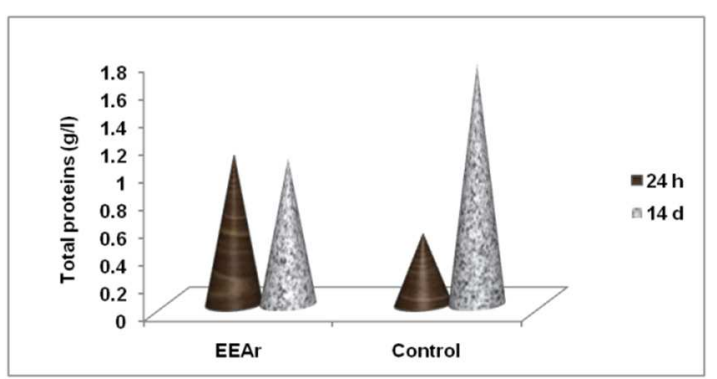

Fig. 10: Effect of EEAr $(2000 \mathrm{mg} / \mathrm{kg})$ on total proteins, $\mathrm{n}=3$, results represent the means \pm SEM (standard error of mean) 
The total protein (lot II) treated with EEar showed no significant difference $(p>0.05)$ after $14 d$, whereas those of the control (lot $I)$ group showed a significant difference $(\mathrm{p}<0.05)$.

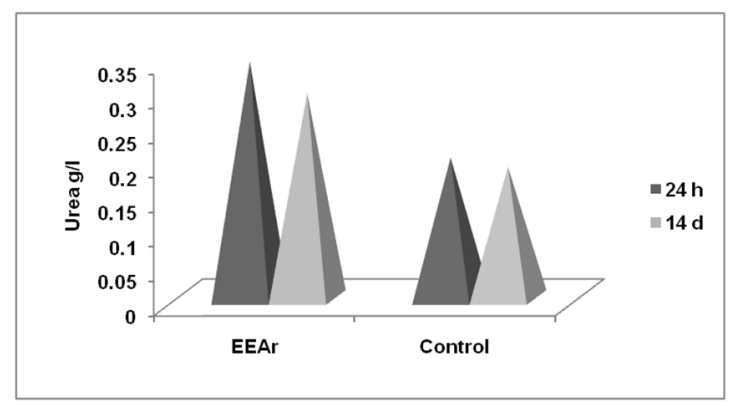

Fig. 11: Effect of EEAr $(2000 \mathrm{mg} / \mathrm{kg})$ on urea, $\mathrm{n}=3$, results represent the means $\pm S E M$ (standard error of mean)

The urea of (lot II) treated with EEAr and the control lot (lot I) showed no significant difference ( $p>0.05$ ) after $14 \mathrm{~d}$.

It is important to note that except of blood glucose (fig. 3 ) and total proteins (fig. 10) of the control batch, the contents of which are $24 \mathrm{~h}$ after administration and $14 \mathrm{p}<0.05$ ), other biochemical parameters such as ALAT/GTP transaminases (fig. 5) and ASAT/GOP (fig. 4), total bilirubin's (fig. 7), and conjugated (fig. 8), alkaline phosphatase (fig. 6), creatinine (fig. 9), and urea (fig. 11) Show statistically insignificant difference ( $p>0.05)$ in test (II) and control batch (I).

The variations in glycemia and total proteins in the control batch may be related to the result between inputs (food, synthesis, mobilization of reserves) and outputs (storage, catabolism, elimination). The EEAr had no effect on plasma biochemical parameters.

With regard to the results obtained, we can deduce that the EEAr leaves proved to be non-toxic for the parameters tested, thus has no influence on the blood tissue and then on the vital organs such as the liver and the kidneys. This shows practically the safety of this plant used in the treatment of hepatitis by some traditional healers and herbalists in Benin. Serum enzymes ASAT, ALAT are enzymes synthesized in the cytoplasm of the cell and discharged into the circulation in the case of damaged cells [17].

These are considered good indicators of hepatic cytolysis. Thus, high levels of liver enzymes, including ALAT and ASAT, are frequently attributed to the metabolic and/or toxic effects of different drugs such as psychotropic drugs [18]. At $2000 \mathrm{mg} / \mathrm{kg}$ body weight the extract caused a slight, non-significant increase in ASAT while the ALAT did not increase. The realization of the histological sections will allow us to confirm these observations.

These results are comparable to those obtained by [10] with the Argemone mexicana L., where they did not notice the variation of biochemical parameters during sub-chronic toxicity. This shows the safety of the aqueous extract of this plant.

Our results are partly comparable to those of [19] who are not arrested for acute toxicity but have further investigated their work by the subacute toxicity of the extracts of Aristolochiae fructus (A. fructus) and Honey-Fried Aristolochiae fructus (H. A. fructus) in Rodents. The subacute toxicity results showed a dose-dependent relationship of nephrotoxicity of $A$. fructus and $H$. A. fructus. However, the toxicity of $A$. fructus was higher than that of $H$. A. fructus. Even when the content of aristolochic acids was equivalent, the toxic effect of $A$. fructus was more severe than $H$. A. fructus.

The likely explanation can be attributed to differences in the pharmacokinetics or toxicokinetics of A. fructus and H. A. fructus and require further study. Clinical doses of $A$. fructus and $H$. A. fructus are $3.0 \mathrm{~g} / \mathrm{d}$ for adults. They conclude that Honey and decoction with water may decrease aristolochic acids contents, and mitigate toxic effects.
Like This, some medications carry the indications "slightly toxic", "toxic" and "extremely toxic" an overdose. In order to mitigate or eliminate their toxicity and the secondary effects of these drugs, a plethora of theory and technique are frequently used whose main methods of toxicity elimination are drug treatment and compatibility. Some plants containing aristolochic acids such as $A$. manushuresis $[20,21], A$. fangchi $[22,23]$ and A. radix [24] have been reported on the possibility of reducing toxicity by drug therapy $[24,25]$ and compatibility $[20,23]$.

\section{CONCLUSION}

The acute toxicity tests in vivo of EEAr leaves showed no toxic effect on the biochemical and haematological parameters studied at 2000 $\mathrm{mg} / \mathrm{kg}$. The lethal dose is therefore over $2000 \mathrm{mg} / \mathrm{kg}$. These results appear to be in favor of its use in hepatitis treatment in some areas of Benin. However, other studies such as chronic or subchronic toxicity tests in vivo of extracts $A$. albida Duch and histological examinations of the organs (liver and kidney) deserve to be carried out in order to confirm it's a toxic character.

\section{ACKNOWLEDGMENT}

To the Superior Ministry of Education and Scientific Research for its financial support. To the teachers; Prof Patrick A. Edorh, Prof Hyacinthe Ahissou for their valuable contributions and advice in the realization of this work.

\section{CONFLICT OF INTERESTS}

The authors declare that there is no conflict of interests regarding the publication of this paper.

\section{REFERENCES}

1. Médecine et santé [en ligne]; 2014. Available from: http://www.medecine-et-sante.com/maladies explications/hepatites.html. [Last accessed on 01 Dec 2016]

2. Guinnin FDF, Sacramento TI, Sezan A, Ategbo JM. Etude ethnobotanique des plantes medicinales utilisées dans le traitement traditionnel des hépatites virales $\mathrm{B}$ et $\mathrm{C}$ dans quelques départements du Bénin. Int J Biol Chem Sci 2015;9:1354-66.

3. APG. An update of the angiosperm phylogeny group classification for the orders and families of flowering plants: APG III. Botan J Linn Soc London 2009;61:105-12.

4. Siabana A. Etude de la phytochimie et des activités biologiques de Aristolochia albida Duch. utilisé dans le traitement des douleurs abdominales. Thèse de doctorat en pharmacie: Université de Bamako; 2009. p. 93.

5. Akoègninou A, van der Burg WJ, van der Maesen LJG. Flore analytique du bénin. Backhuys Publishers: Wag; 2006. p. 1034.

6. Guinnin FDF, Sacramento TI, Ategbo JM, Agbangnan CDP. Physicochemical composition and radical-scavenging activity evaluation of the extracts of Aristolochia albida Duch. of Benin. J Appl Biosci 2016;107:10460-70.

7. OCDE. Sous-comité d'experts du système général harmonisé de classification et d'étiquetage des produits chimiques: dangers pour la santé et l'environnementtoxicité aiguë. UN/SCEGHS/ 2/INF; 2001. p. 13.

8. Sodipo OA, Abdulrahman FI, Alemika TE, Gulani IA. Chemical composition and biological properties of the petroleum ether extract of Solanum macrocarpum L. Br J Pharm Res 2012;2:108-28.

9. Cherif HS, Saidi F, Guedioura A. Toxicological evaluation of Aristolochia longa L. extract in mice. Indian J Appl Res 2014;4:26-30.

10. Guirou C. Etude de la toxicité sub-chronique de Argemone mexicana utilisée dans le traitement traditionnelle du paludisme. Thèse de Pharmacie, FMPOS: Université de Bamako; 2008. p. 82.

11. Hilaly JE, Israili ZH, Lyouss B. Acute and chronic toxicological studies of Ajuva Iva in experimental animals. J Ethnopharm 2004;91:43-50.

12. Gazda VE, Gomes-Carneiro MR, Barbi NS, Paumgartten FJR. Toxicological evaluation of an ethanolic extract from Chiococca alba roots. J Ethnopharm 2006;105:187-95.

13. Rebecca MA, Ishii-Iwamoto EL, Grespan R, Cuman RKN, Caparroz-Assef SM, Mello JCP, et al. Toxicological studies on Stryphnodendron adstringens. J Ethnopharm 2002;83:10-104. 
14. Bello I, Bakkouri AS, Tabana YM, Al-Hindi B, Al-Mansoub MA Mahmud R, et al. Acute and sub-acute toxicity evaluation of the methanolic extract of alstonia scholaris stem Bark. Med Sci 2016;4:4

15. Maduka HC, Okoye ZS, Eje A. The influence of Sacoglottis gabonensis stem bark extract and its isolated bergenin, Nigerian alcoholic beverage additives, on the metabolic and haematological side effects of 2,4-dinitrophenyl hydrazine induced tissue damage. Vas Pharm 2003;39:317-24.

16. Kone M, Bleyere NM, Yapo AP, Vangah M, Ehile EE. Evaluation de la toxicité d'un extrait aqueux de Sacoglottis gabonensis (Baille) Urban (Humiriaceae) chez les rongeurs, une plante utilisée dans le traitement de l'ulcère de Buruli en Côte d'Ivoire. Int J Biol Chem Sci 2009;3:1286-96.

17. Ozturk IC, Ozturk F, Gul M, Ates B, Cetin A. Protective effects of ascorbic acid on hepatotoxicity and oxidative stress caused by carbon tetrachloride in the liver of Wistar rats. Cell Biochem Func 2009;27:309-15.

18. Himmerich H, Kaufmann C, Schuld A, Pollmacher T. Elevation of liver enzyme levels during psychopharmacological treatment is associated with weight gain. J Psych Res 2005; 39:35-42.

19. Yuan JB, Huang Q, Gang R, Shi M, Chen L, Yang W, et al. Acute and subacute toxicity of the extract of Aristolochiae Fructus and honey-fried Aristolochiae Fructus in rodents. Biol Pharm Bull 2014;37:387-39.

20. Hu SL, Zhang HQ, Chan K, Mei QX. Studies on the toxicity of Aristolochia manshuriensis (Guanmuton). Toxicology 2004; 198:195-201.
21. Wang ZM, You LS, Jiang X, Li L, Wang WH, Wang G. Methodological studies on selectively removing toxins in Aristolochiae manshuriensis by Chinese processing techniques. Zhongguo Zhong Yao Za Zhi 2005;30:1243-6.

22. Hu SL, Zhang HQ, Chen JQ, Mei QX, Gao YQ, Zhong XW, et al. Preliminary study of the toxicity of Aristolochiae fangchi. Zhong Yao Cai 2003;26:274-6.

23. Yang HY, Zheng XH, Du Y, Chen Z, Zhu DY, Lou YJ. Kinetics of aristolochic acid I after oral administration of Radix Aristolochiae or Guanxinsuhe preparation in canines. J Ethnopharmacol 2011;135:569-74.

24. Wang JH, Wang ZM, Jiang $X$, Xue BY, Li CY. Pharmacodynamic and toxicologic comparative study of crude and processed Radix Aristolochiae. Zhongguo Zhong Yao Za Zhi 2007;32:428-33.

25. Li ZH, Yang B, Yang WL, Chen HF, Yang M, Yuan JB, et al. Effect of honey-toasting on the constituents and contents of aristolochic acid analogues in Aristolochiae Fructus. Zhong Yao Cai 2013;36:538-41.

\section{How to cite this article}

- $\quad$ Felix FD Guinnin, Jean-Robert Klotoe, Jean-Marc Ategbo. Acute toxicity evaluation of ethanolic extract of Aristolochia albida duch. leaves on wistar rats liver and kidney functions. Int J Pharm Pharm Sci 2017;9(7):35-40. 